\title{
Pemberdayaan Ekonomi Pengrajin Batik Eco Print Yang Berdaya Saing Dimasa New Normal Covid 19
}

\author{
Trias Setyowati, Fefi Nurdiana Wijayanti \\ Universitas Muhammadiyah Jember \\ Email: trias@ unmuhjember.ac.id, fefinurdiana@unmuhjember.ac.id
}

Diterima: Mei 2021 | Dipublikasikan: Juni 2021

\begin{abstract}
ABSTRAK
Pengabdian masyarakat dengan judul "Pemberdayaan Pengrajin Batik Ecoprint Yang Berdaya Saing Dimasa New Normal covid19" adalah bertujuan untuk mengatasi masalah yang dihadapi UKM pengrajin Batik Ecoprint di Kelurahan Jember Lor, Kecamatan Patrang, Kabupaten Jember yaitu (1) Kurangnya alat produksi dan permodalan untuk membeli bahan baku kain untuk memenuhi permintaan pasar yang mulai meningkat (2) Sistem pemasaran yang masih konvensional dan belum memanfaatkan e commerce dan media sosial (3). Metode pelaksanaan tahapannya adalah : (a) Sosialisasi program pengabdian masyarakat; (b) Persiapan prakondisi sosial, yakni penguatan pengrajin Batik Ecoprint (c) Pelaksanaan program dengan memberikan alat-alat produksi berupa steamer langseng kapasitas besar, (d) penyuluhan tentang sistem pemasaran secara e-commerce dan pemasaran yang memanfaatkan media sosial facebook dan instagram; (e) Pemantauan, evaluasi dan pelaporan. Hasil Kegiatan : yaitu dengan memberikan bantuan berupa alat produksi steamer langsengdengan kapasitas 20 peace untuk setiap kali produksi dan bahan kain untuk pembuatan batik Ecoprint, (2) melakukan kegiatan pelatihan kepada pemilik dan karyawan UMKM Yuniar Batik tentang sistem pemasaran berbasis tehnologi informasi, melalui pemanfaatan media online di Face book, youtube dan instagram, sehingga daya jangkau penjualan menjadi lebih luas. pelatihan perbaikan mutu produk yang lebih menarik dan marketable, seperti dengan membuat baju, masker dan tas yang memiliki daya saing dengan batik cap bahkan batik tulis. Kesimpulan dari kegiatan ini adalah penting sekali untuk terus meningkatkan kemampuan dalam memasarkan produk melalui promosi di media sosial seperti facebook, instagram dan facebook dan juga peningkatan keterampilan dari pemilik UKM Yuniar Batik sehingga Eco print akan menjadi produk yang memiliki daya saing dan makin beragam, yang semula batik eco print ini dibuat hanya untuk hijab, saat ini semakin dikembangkan menjadi tas dan masker, Saran dari tim pelaksana pengabdian adalah kegiatan semacam ini harus dilakukan secara terus menerus dalam bentuk pembinaan dan pendampingan agar produk yang dihasilkan semakin baik dan jumlah penjualan semakin meningkat sehingga berdampak terhadap peningkatan pendapatan pemilik UMK Yuniar Batik.
\end{abstract}

Kata Kunci: pemberdayaan Ekonomi, eco print batik, berdaya saing

\section{ABSTRACT}

The purpose of the community service activity entitled "Empowerment of Competitive Ecoprint Batik Craftsmen in the New Normal Covid19 Period" is to address the main problems faced by Batik Ecoprint craftsmen UKM in Jember Lor Village, Patrang District, Jember Regency, namely (1) Lack of production equipment and capital for buying raw materials for fabrics to meet increasing market demand (2) Marketing systems that are still conventional and have not taken advantage of e-commerce and social media (3). The implementation method to solve the problems of partners in the partnership program to the community is (1) assistance to purchase production equipment in the form of large capacity steamer and cloth as materials for making Ecoprint batik, (2) training in marketing systems through the use of online media on Face book and Instagram, as for the stages are: (a) Socialization of community service programs; (b) Preparation of social preconditions, namely strengthening Batik Ecoprint craftsmen (c) Implementation of the program by providing production tools in the form of large capacity direct steamers, (d) counseling on e-commerce and marketing systems using social media Facebook and Instagram; (e) Monitoring, evaluation and reporting. Results of activities that have been carried out by the implementing team to partners: namely by providing assistance in the form of direct steamer production equipment with a capacity of 20 peace for each production and fabric for making Ecoprint batik, (2) conducting training activities for owners and employees of Yuniar Batik MSMEs regarding the system. information technology-based marketing, through the use of online media on Face book, YouTube and 
Instagram, so that sales reach is wider. training to improve the quality of products that are more attractive and marketable, such as by making clothes, masks and bags that are competitive with printed batik and even hand-drawn batik. The conclusion of this activity is that it is very important to continue to improve the ability to market products through promotion on social media such as Facebook, Instagram and Facebook and also to improve the skills of the Yuniar Batik UKM owners so that Eco print will become a product that has more competitiveness and is more diverse, which was originally This eco print batik is made only for hijab, currently it is increasingly being developed into bags and masks. Suggestions from the community service implementation team are that this kind of activity must be carried out continuously in the form of coaching and assistance so that the products produced get better and the number of sales increases so that it has an impact. to the increase in income of UMK Yuniar Batik owners

Keywords: Economic empowerment, eco print batik, competitiveness

\section{PENDAHULUAN}

Era perdagangan bebas, memunculkan berbagai macam tantangan yang dihadapi tidak hanya dari aspek ketersediaan sumber daya manusia (SDM) yang siap bekerja, akan tetapi juga menyiapkan dan menciptakan lapangan pekerjaan baru. Realitas dan kondisi yang ada di Indonesia dewasa ini, menghadirkan suatu cara pandang dalam berfikir bahwa masyarakat Indonesia dididik untuk menjadi para pencari kerja. Dengan kondisi perekonomian yang tidak stabil, kemapanan dan keamanan dalam bekerja adalah tujuan utama, dan kemapanan tersebut didapat setelah menjadi karyawan yang mendapat gaji bulanan yang tetap. Hal ini berakhir dengan masalah pengangguran yang merupakan penyakit yang bersifat struktural dan kronis yang melanda seluruh negara berkembang, disebabkan karena mereka yang mencari pekerjaan setiap tahun terus bertambah, sedangkan lapangan pekerjaan yang tersedia tidak mencukupi. Indonesia begitu kaya dengan potensi budaya dan jumlah penduduk yang besar merupakan potensi dalam pengembangan ekonomi kreatif. Sistem ekonomi kreatif diyakini mampu menjadi solusi dalam mengatasi masalah tersebut, sekaligus sebagai alternatif dalam menghadapi tantangan ekonomi global yang akan menggeser sistem ekonomi yang telah berjalan. Indonesia yang kaya akan budaya dan berpenduduk besar mempunyai potensi yang sangat besar dalam pengembangan ekonomi kreatif (Noviyanti, 2017)

Potensi sumber daya alam berupa bentang alam yang luas dan menyediakan bahanbahan yang dapat dikembangkan untuk kegiatan industri, menjadikan sebagai penyokong pengembangan potensi ekonomi. Kondisi perekonomian di Indonesia salah satunya ditopang oleh perekonomian Usaha Kecil Menengah (UKM).( (Kumalasari, 2014) Dapat dikatakan bahwa industri kecil adalah sebagai salah satu usaha untuk meningkatkan pendapatan keluarga dan memberikan lapangan pekerjaan serta dapat memenuhi kebutuhan masyarakat (Prabawa et al., 2020)

Meningkatnya kesadaran masyarakat menjaga kelestarian alam menjadikan trend gaya hidup ramah lingkungan semakin digemari dan merambah luas ke berbagai sector usaha. Tidak terkecuali dengan trend adi busana khusunya batik. Akhir-akhir ini berkembang batik Ecoprint, yakni batik kontemporer yang menambah khasanah batik etnik di samping batik tulis dan batik cap. Sesuai namanya ecoprint dari kata eco asal kata ekosistem (alam) dan print yang artinya mencetak, batik ini dibuat dengan cara mencetak dengan bahan-bahan yang terdapat di alam sekitar sebagai kain, pewarna, maupun pembuat pola motif. Bahan yang digunakan berupa dedaunan, bunga, batang bahkan ranting. Penggunaan bahan alam untuk pewarnaan batik sejalan dengan konsep pemanfaatan produk ramah lingkungan dengan memanfaatan sumbersumber pewarna alami. Di beberapa negara seperti Jerman dan Belanda, telah dilakukan pelarangan penggunaan zat pewarna berbahan kimia sejak tahun 1996. Oleh karena itu, mulai bermunculan produk-produk tekstil yang menggunakan bahan pewarna alami, khususnya batik.(Alamsyah, 2018). Tidak seperti batik tulis atau cap yang pada tahap tertentu menggunakan bahan kimia. Ecoprint menggunakan bahan-bahan alami yang banyak tersedia dan cukup melimpah disekitar. Selain itu, dapat mengurangi/meminimalisir biaya produksi. Dengan demikian, batik ini sangat ramah lingkungan dan tidak menimbulkan pencemaran air, 
tanah atau udara (www.mediacenter, 2019). Membuat ecoprint butuh seni. Memanfaatkan keindahan alam. Ini yang menjadi nilai mahal dalam setiap lembar kain ecoprint," ujar penggiat ecoprint Surabaya Didik Edy Susilo. (Jawapos, 2020), salah satu UKM yang saat ini sedang mengembangkan batik Eco Print di Jember adalah Yuniar Batik, berikut ini merupakan profil UKM Yuniar Batik, sebagai mitra dalam kegiatan pengabdian masyarakat ini

\section{A. Profil UKM Yuniar Batik}

Trend gaya hidup ramah lingkungan inilah yang mendasari Yuniar Widiana menekuni dan mengembangkan batik Ecoprint dengan Branding Yuniar Batik. Yuniar mengolah bahan alami menjadi kerajinan baju dan hijab. Yuniar memulai usahanya sejak 2016 sampai sekarang. Disekitar rumah Yuniar ditanam beberapa tanaman yang dipakai sebagai bahan alami batiknya. Beberapa daun yang dipakai oleh Yuniar adalah daun jati, daun lanang, daun jambu biji. Jenis kulit kayu yang dipakai adalah Mahoni, tinggi, tegera,indigofera dan secang. Juga memakai Kunyit sebagai pewarna.

Salah satu jenis zat warna sintetik yang banyak digunakan dalam industri tekstil adalah zat warna remazol. Zat warna ini banyak digunakan karena sifatnya yang mudah larut dalam air dan tidak terdegradasi pada kondisi biasa. Sebagian besar zat warna sengaja dibuat supaya mempunyai ketahanan terhadap pengaruh lingkungan seperti efek $\mathrm{pH}$, suhu dan mikroba. Oleh karena itu, limbah dari zat warna remazol sangat berpotensi mencemari lingkungan apabila tidak dilakukan pengolahan terlebih dahulu. Akibatnya, air menjadi tercemar (berwarna) dengan kualitas air semakin memburuk dan tidak layak digunakan (Sukarta \& Sastrawidana, 2014). Bahan kimia yang digunakan dalam industri batik seperti Soda api (NaOH), Sodium nitrit (NaNO2), Soda api $(\mathrm{NaOH})$, Sodium silikat (Na2SiO3) dan pewarna batik seperti Naptol. Bahaya yang disebabkan oleh bahan kimia dan pewarna batik tersebut dapat berupa iritasi, gatal pada kulit bahkan sampai kanker kulit. Oleh karena itu, pada pengabdian masyarakat kali ini akan memberikan solusi dalam meminimalisir kesalahan yang menimbulkan kesehatan menurun terutama dalam proses pewarnaan.(Ahda et al., 2019)

Di Indonesia terdapat banyak sekali bahan pewarna alternatif yang lebih aman dan tahan lama yang berasal dari tanaman, untuk itu agar hasil pembuatan batik tidak terlalu mencemari lingkungan dan membahayakan manusia, maka bahan pewarna sintetis tersebut harus diganti dengan pewarna dari alam. Yuniar Batik, selain menggunakan pewarna sintetis, juga sudah menggunakan warna alami yang berasal dari kayu Mahoni, Tinggi, Tegeran, Indigofera, Secang. Dengan adanya program pengabdian ini diharapkan Yuniar Batik dalam proses produksinya menggunakan bahan alami semua yang aman bagi lingkungan. Selain penggunaannya praktis, zat warna yang dihasilkan tanaman-tanaman tersebut kualitasnya tidak kalah dengan pewarna sintetis, pewarna alami yang terlihat lembut, tetapi dari segi pamor secara keseluruhan warna alami jelas lebih cantik.

Mewabahnya Pandemi Covid-19 tidak hanya semata-mata berdampak pada bidang kesehatan, namun juga mulai menggerogoti omset Usaha Kecil Menengah (UKM) seperti halnya Yuniar Batik, yang dikelola bersama suaminya di Jalan Nusa Indah V No.153 Kelurahan Jember Lor, Kecamatan Patrang, Kabupaten Jember. Pengelola Yuniar Batik merasakan terjadinya penurunan omset hingga 85\% terhitung sejak Maret 2020. Biasanya setiap bulan sebelum pandemi bisa menjual 12-15 lembar kain batik, namun setelah pandemi hanya 1-2 lembar saja, dengan harga Rp 150.000 - Rp 500.000/ lembar. Menurunnya daya beli masyarakat pada saat ini membuat pemilik Yuniar Batik memutar otak agar usaha ini terus berjalan dan bertahan, dengan gencar melakukan pemasaran produknya melalui sosial media Instagram milik pribadinya, yaitu ning.ethanbatik.

Menurut Yuniar disaat pandemi ini pesanan Yuniar Batik mulai sepi dan modal usaha mulai menipis, dari segi produksi harga bahan baku memang tidak mengalami kenaikan namun karena daya beli masyarakat yang menurun maka produksi juga menurun sehingga Yuniar merumahkan tenaga kerja karena tidak ada yang harus dikerjakan dan tidak bisa memberi gaji. Yuniar berharap Peranan Pemerintah untuk memakai produk UKM harus ditingkatkan karena saat sekarang ini kalau diandalkan kunjungan dari luar daerah masih sangat susah karena rasa 
kekhawatiran masyarakat terhadap penyebaran Covid-19 masih tinggi, dan ini berdampak pada omset UKM.

\section{B. Keterbatasan Mitra (UKM Yuniar Batik}

Melihat adanya fakta di lapangan tersebut, maka kami sebagai Pengusul tergerak untuk membantu mengusulkan bantuan melalui kegiatan Program Pemberdayaan Masyarakat Universitas Muhammadiyah Jember dengan melakukan kerjasama dengan Mitra UKM Yuniar Batik, yang sudah cukup lama memulai usaha Batik Ecoprint ini, selama ini permintaan konsumen cukup tinggi terhadap Batik Ecoprint selain batik tulis yang juga dihasilkan, akan tetapi permintaan yang cukup tidak dapat dipenuhi secara cepat disebabkan karena keterbatasan permodalan dan peralatan produksi yang dimiliki.

Tabel 1. Data Permintaan dan Penjualan 2019/2020 UKM Yuniar Batik

\begin{tabular}{|c|l|c|c|}
\hline No & \multicolumn{1}{|c|}{ Tahun 2020 } & $\begin{array}{c}\text { Permintaan } \\
\text { (lembar) }\end{array}$ & $\begin{array}{c}\text { Jumlah } \\
\text { Penjualan } \\
\text { (lembar) }\end{array}$ \\
\hline 1 & Januari 2020 & 19 & 15 \\
\hline 2 & Februari 2020 & 15 & 12 \\
\hline 3 & Maret 2020 & 1 & 2 \\
\hline 4 & April 2020 & - & 1 \\
\hline 5 & Mei 2020 & - & 2 \\
\hline 6 & Juni 2020 & - & - \\
\hline 7 & Juli 2020 & - & 1 \\
\hline 8 & Agustus 2020 & 20 & 11 \\
\hline 9 & September 2020 & 15 & 13 \\
\hline 10 & Oktober 2020 & 18 & 12 \\
\hline 11 & Nopember 2020 & 16 & 10 \\
\hline 12 & Desember 2020 & 17 & 93 \\
\hline & Total & 121 & \\
\hline
\end{tabular}

Sumber : UKM Batik Yuniar 2020

Melihat potensi dari data permintaan Yuniar Batik diatas dengan data Penjualannya, maka dapat kita lihat ada margin yang sangat signifikan pada jumlah produksi. Ada margin antara 3-7 lembar batik yang tidak dapat diproduksi karena kurangnya kapasitas alat steamer langseng, sehingga tidak bisa memenuhi permintaan. Permintaan juga belum bisa dipenuhi karena pada saat musim penghujan kain tidak bisa cepat kering sehingga tidak bisa segera dijual, sehingga membutuhkan alat blower untuk mengeringkan kain agar cepat kering. Setelah selesai kain seharusnya di jemur namun karena kurangnya alat penjemuran maka terkadang kain dilipat sehingga membuat warna motif menjadi tidak jelas. Dan setelah kering seharusnya di display, namun karena kurangnya alat display maka kain hanya bisa dilipat sehingga ketika pembeli melihat menjadi tidak rapi. Terkadang tidak jadi membeli, karena itu dibutuhkan packaging yang memiliki ciri khas, dan elegan. Ciri khas packaging yang digunakan terbuat dari bahan alami yang terbuat dari bambu dan banyak tersedia dilokasi kedua UKM. Persoalan dalam aspek pemasaran menjadi kendala juga UKM Yuniar, masih terbatasnya media untuk memasarkan hasil produk, sehingga memiliki daya jangkau yang lebih luas.

Hasil observasi bersama mitra dalam menentukan persoalan yang benar-benar merupakan permasalahan prioritas mitra UKM Yuniar Batik, Kabupaten Jember adalah :

1) Permintaan terhadap Batik Ecoprint yang meningkat karena masyarakat sudah peduli dengan produk yang berbahan alami dan mempunyai corak yang khas, akan tetapi proses produksi terbatas karena terkendala dana untuk membeli bahan;

2) keterbatasan pengetahuan tentang pewarnaan alami dan sintetis, sehingga desain produk yang dihasilkan masih monoton dan tidak ada inovasi dengan bahan alami agar lebih disukai konsumen;

3) keterbatasan alat produksi berupa steamer langseng untuk mengukus kain menyebabkan proses produksi masih sangat terbatas jumlahnya; 
4) sistem pemasaran masih konvensional dan belum memanfaatkan media sosial yang sudah sangat dikenal oleh semua kalangan, menyebabkan terbatasnya wilayah pemasaran yang hanya di sekitar Kabupaten Jember;

5) belum adanya pengembangan ragam bentuk hasil produk akhir yang dibuat sehingga sulit untuk bisa bersaing dengan produk sejenis, misalkan produk eco print yang dibuat hanya berupa hijab saja.

UMKM Yuniar Batik sebagai salah satu yang mengembangkan batik eco print dengan menggunakan bahan-bahan alami yang diberasal dari tumbuhan dan daun-daunan yang banyak tersedia dari lingkungan sekitar, ini sangat sejalan dengan upaya UM Jember yang tertuang dalam rencana strategis pengabdian untuk melakukan optimalisasi pengembangan ekonomi kreatif desa berbasis kearifan lokal dan kewirausahaan, akan tetapi Yuniar batik masih mengalami beberapa kendala dalam kegiatan produksinya. Berdasarkan hasil observasi terhadap mitra dalam menentukan persoalan yang benar-benar merupakan permasalahan prioritas mitra UKM Yuniar Batik, Kabupaten Jember, maka solusi yang ditawarkan adalah :

Pentingnya untuk melakukan pendampingan dan pembinaan terhadap mitra yaitu Yuniar Batik agar keberadaan usaha ini, bisa lebih berkembang sehingga akan memberikan dampak terhadap peningkatan volume penjualan, , solusi untuk menyelesaikan permasalahan mitra dalam pelaksanaan program ini adalah meningkatkan jumlah produksi yang dihasilkan dan perbaikan kualitas atau mutu dari produk eco print batik, jangkauan pemasaran yang lebih luas, efisiensi biaya sehingga akan meningkatkan pendapatan pengrajin batik eco print. Hal ini dapat diuraikan secara rinci sebagaian berikut:

Tabel 2. Solusi dan Target Luaran

\begin{tabular}{|c|c|c|c|}
\hline No & $\begin{array}{l}\text { Permasalah } \\
\text { an }\end{array}$ & Solusi Kegiatan & Target Luaran \\
\hline 1 & $\begin{array}{l}\text { Belum } \\
\text { Optimalnya } \\
\text { Jumlah } \\
\text { Produksi } \\
\text { disebabkan } \\
\text { keterbatasan } \\
\text { modal berupa } \\
\text { alat produksi } \\
\text { dan skill yang } \\
\text { dimiliki }\end{array}$ & $\begin{array}{l}\text { Sharing Season tentang } \\
\text { waktu dan jadwal kegiatan } \\
\text { Program serta penyuluhan } \\
\text { dan informasi terkait } \\
\text { Program, pemberian bantuan } \\
\text { alat produksi berupa steamer } \\
\text { pengukus dan kompor gas. }\end{array}$ & $\begin{array}{l}\text { Adanya kesepakatan kerjasama antara } \\
\text { pihak Pengusul dan Mitra dan } \\
\text { peningkatan produksi }\end{array}$ \\
\hline 2 & $\begin{array}{l}\text { Rendahnya } \\
\text { kualitas } \\
\text { produk } \\
\text { teritama } \\
\text { dari sisi } \\
\text { desain dan } \\
\text { pewarnaan }\end{array}$ & $\begin{array}{l}\text { Pendampingan Penguatan } \\
\text { dan Peningkatan } \\
\text { Pengenalan Pewarna alami } \\
\text { dan sintetis serta cara } \\
\text { mendesain produk Batik } \\
\text { Ecoprint yang inovatif dan } \\
\text { kreatif kepada mitra. }\end{array}$ & $\begin{array}{l}\text { Peningkatan pengetahuan } \\
\text { tentang jenis pewarna alami sebagai } \\
\text { bahan pewarna yang mudah didapat dan } \\
\text { murah. Peningkatan keterampilan dan } \\
\text { kemampuan mendesain produk batik } \\
\text { Ecoprint yang lebih marketable }\end{array}$ \\
\hline 3 & $\begin{array}{l}\text { Terbatasnya } \\
\text { Jaringan } \\
\text { pemasaran, } \\
\text { karena masih } \\
\text { belum } \\
\text { memanfaatkan } \\
\text { jaringan e- } \\
\text { commerce }\end{array}$ & $\begin{array}{lr}\text { Pendampingan } & \text { dan } \\
\text { pelatihan } & \text { pembuatan } \\
\text { promosi melalui media on } \\
\text { line dan Koordinasi dengan } \\
\text { Lembaga terkait antar Tim } \\
\text { Program r kemitaan } \\
\text { masyarakat dengan } & \text { Dinas } \\
\text { Perindustrian } & \text { dan } \\
\text { Perdagangan, Mitra } & \text { UKM } \\
\text { Batik Yuniar. } & \end{array}$ & $\begin{array}{l}\text { 1. Terlaksananya transfer teknologi } \\
\text { untuk meningkatkan pendapatan } \\
\text { pengrajin Batik Ecoprint } \\
\text { 2. Peningkatan jumlah produsksi dari } \\
\text { Yuniar Batik, karena } \\
\text { menggunakan alat produksi yang } \\
\text { memiliki kapasitas lebih besar, } \\
\text { sehingga bisa memenuhi } \\
\text { permintaan pasar } \\
\text { 3. Peningkatan Kualitas/mutu }\end{array}$ \\
\hline
\end{tabular}




\begin{tabular}{|c|c|c|c|}
\hline & & & $\begin{array}{l}\text { Batik Ecoprint yang lebih baik, } \\
\text { gambar muncul dengan jelas } \\
\text { sehingga bisa menaikkan harga } \\
\text { jual. } \\
\text { 4. Efisiensi Biaya produksi sehingga } \\
\text { juga bisa menaikkan pendapatan } \\
\text { pengrajin Batik } \\
\text { Ecoprint } \\
\text { 5. Peningkatan jejaring pemasaran } \\
\text { dengan memanfaatkan media } \\
\text { promosi online atau e-commerce }\end{array}$ \\
\hline 4 & $\begin{array}{l}\text { Pemantauan, } \\
\text { evaluasi }\end{array}$ & $\begin{array}{l}\text { a) Pemantauan program } \\
\text { b) Evaluasi program } \\
\text { c) Pelaporan }\end{array}$ & $\begin{array}{l}\text { Terlaksananya kegiatan program } \\
\text { kemitraan kepada masyarakat sesuai } \\
\text { rencana. }\end{array}$ \\
\hline
\end{tabular}

METODE PELAKSANAAN

\section{Metode Dan Tahapan Dalam Penerapan Teknologi Kepada UKM}

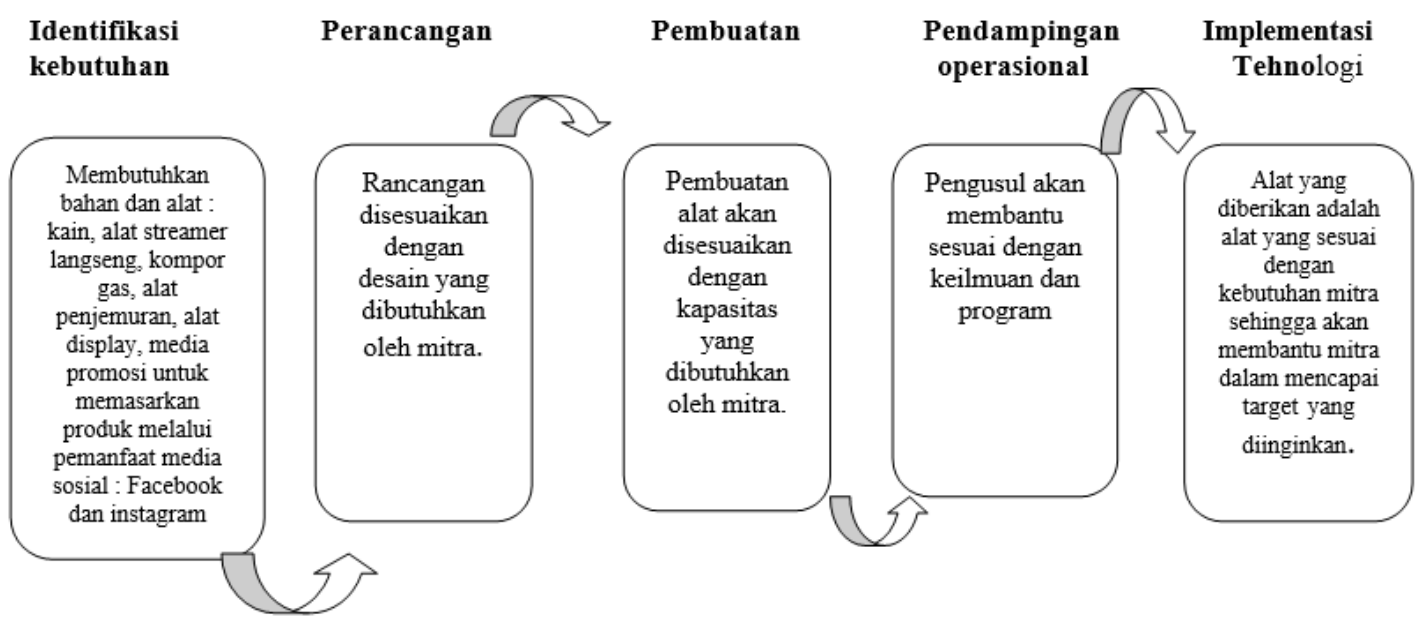

Metode Pelaksanaan Penerapan Tehnologi Pada Mitra Yuniar Batik

\section{Tahapan tahapan Proses pembuatan Eco Print Batik}

\section{Alat dan Bahan}

1. Kain dengan serat alami seperti katun, sutera, atau kanvas

2. Daun-daunan/ bunga

3. Air cuka

4. Palu

5. Campuran air tawas

6. Pipa peralon

7. Tali

8. Panci untuk mengukus 
Tahapan dalam proses pembuatan eco print batik melalui langkah seperti dalam diagram dibawah ini :

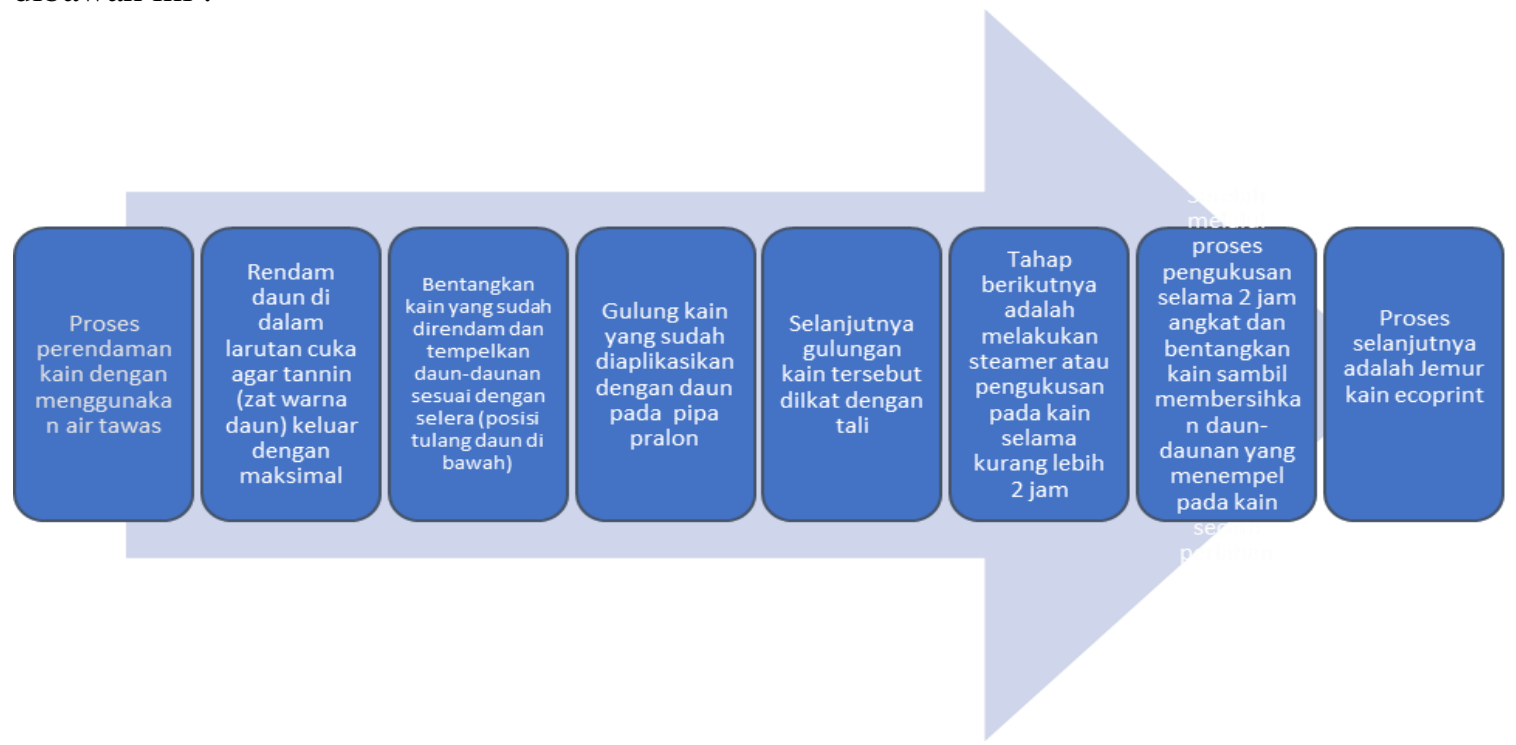

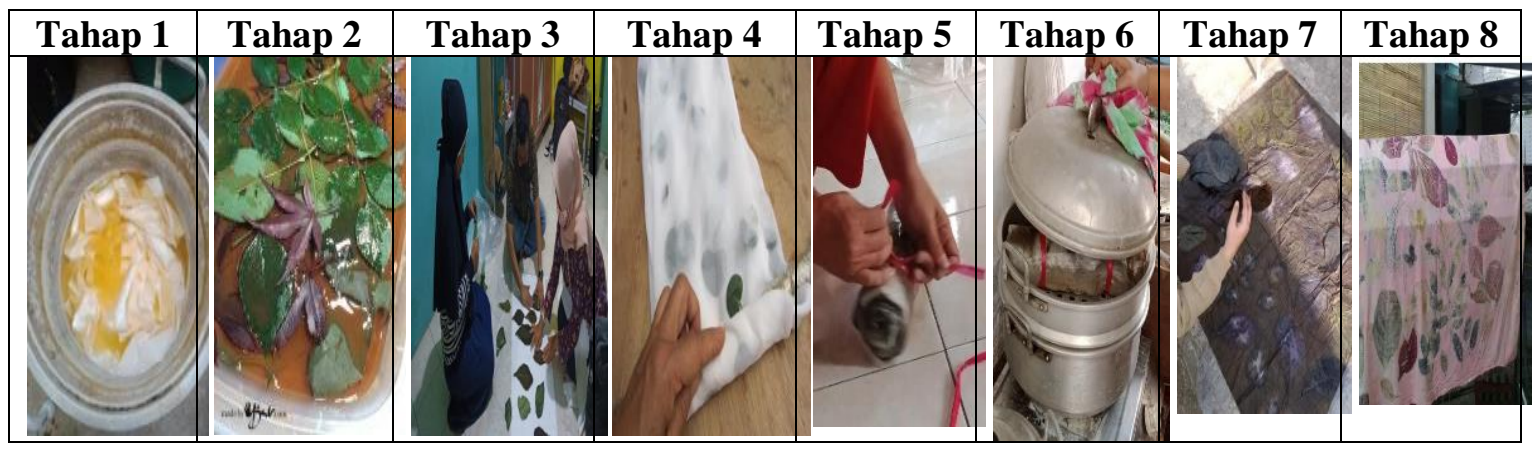

Gambar 2. Tahapan Proses Pembuatan Eco Print Batik

\section{HASIL DAN PEMBAHASAN}

Kegiatan pengabdian masyarakat pada Mitra yaitu UKM Batik Yuniar ini membutuhkan waktu selama 6 bulan, adapun kegiatan yang sudah dilakukan adalah memberikan pelatihan dan pendampingan untuk peningkatan kapasitas produksi berupa pemberian bantuan berupa alat produksi berupa steamer langseng dengan kapasitas 20 peace untuk satu kali produksi, perbaikan dan peningkatan mutu kemasan produk/packanging dengan membuat desain kemasan produk yag lebih menarik dan marketable, kegiatan lain yang dilakukan adalah perbaikan strategi pemasaran dengan memanfaatkan tehnologi informasi berupa pemanfaatan media sosial facebook dan instagram sebagai sarana promosi untuk meningkatkan market share dari produk yang dihasilkan. berikut :

Adapun langkah dan rincian kegiatan yang dilakukan oleh tim pelaksana adalah sebagai 


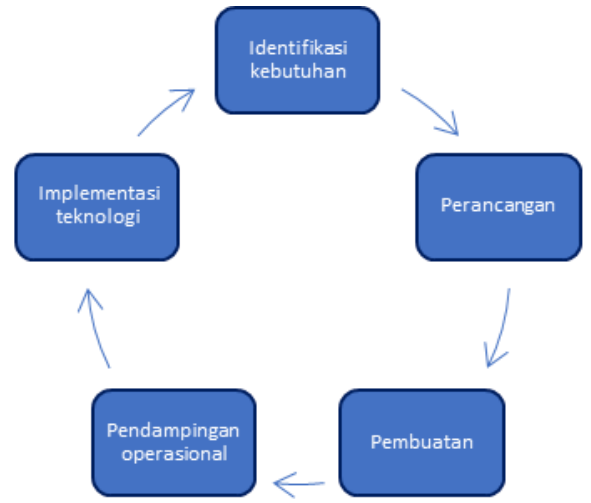

Gambar 3. Tahapan Tahapan pelaksanaan kegiatan Pengabdian

1). Peningkatan Kapasitas Produksi dan perbaikan mutu kemasan produk melalui kegiatan :

a). Pemberian bantuan alat produksi berupa steamer langseng pengukus kain, dengan kapasitas produksi 20 peace untuk setiap proses pengukusan, dengan menggunakan alat yang baru ini memberikan dampak terhadap peningkatan jumlah produk yang dihasilkan dan mampu menekan biaya produksi dari penggunaan bahan bakar gas yang digunakan sehingga terjadi efisiensi terhadap biaya produksi.

b). Pelatihan pembuatan kemasan produk yang lebih menarik dan marketable. Kemasan produk selama ini tidak dilengkapi dengan nama atau brand dan hanya dibungkus dengan kemasan plastik transparan, melalui kegaiatan pengabdian masyarakat ini kemasan produk sudah memiliki brand berupa stiker dan kemasannya jauh lebih menarik dan berdaya saing dipasaran.

2). Penguatan Manajemen Usaha dibidang Pemasaran

- Identifikasi konsumen, target pasar, pangsa pasar serta kapasitas usaha Mitra Batik Yuniar sebagai pemilik usaha

- Pendampingan perancangan strategi pemasaran berbasis sosial media instagram dan facebook

- Pendampingan pembuatan profil pemasaran berbasis sosial media instagram dan facebook

- Pelatihan update profil pemasaran berbasis sosial media instagram dan facebook

- Pelatihan pembuatan desain kemasan yang memiliki ciri khas sehingga memiliki daya saing dengan produk sejenis.

3). Monitoring \& Evaluasi

Kegiatan monitoring dan evaluasi terhadap keberhasilan dilakukan oleh Tim PKM sesuai dengan masing-masing sistematika yang telah dilatihkan sebelumnya.

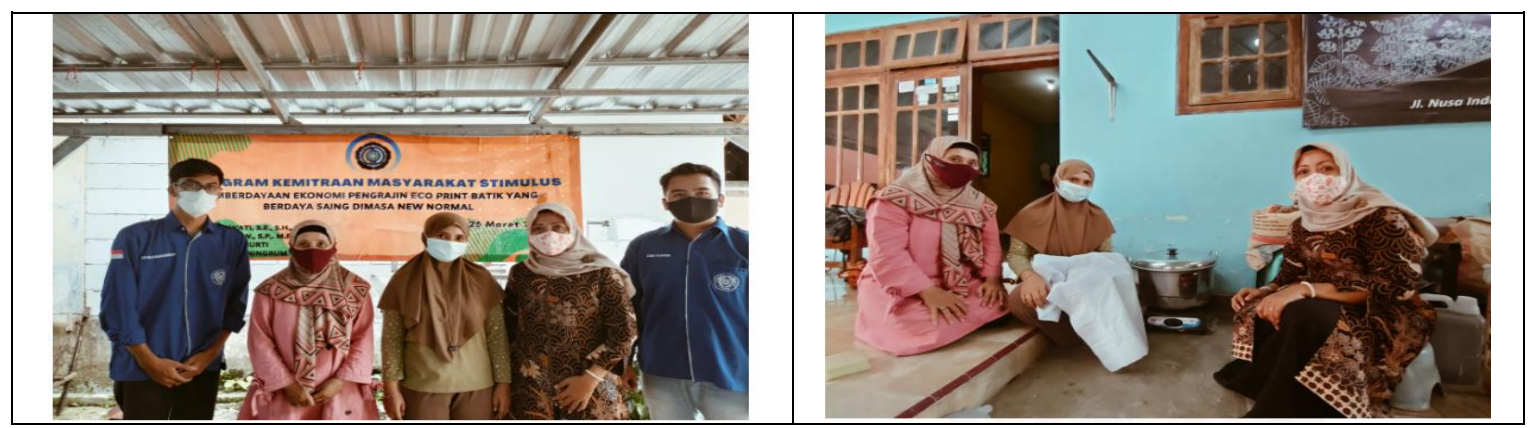




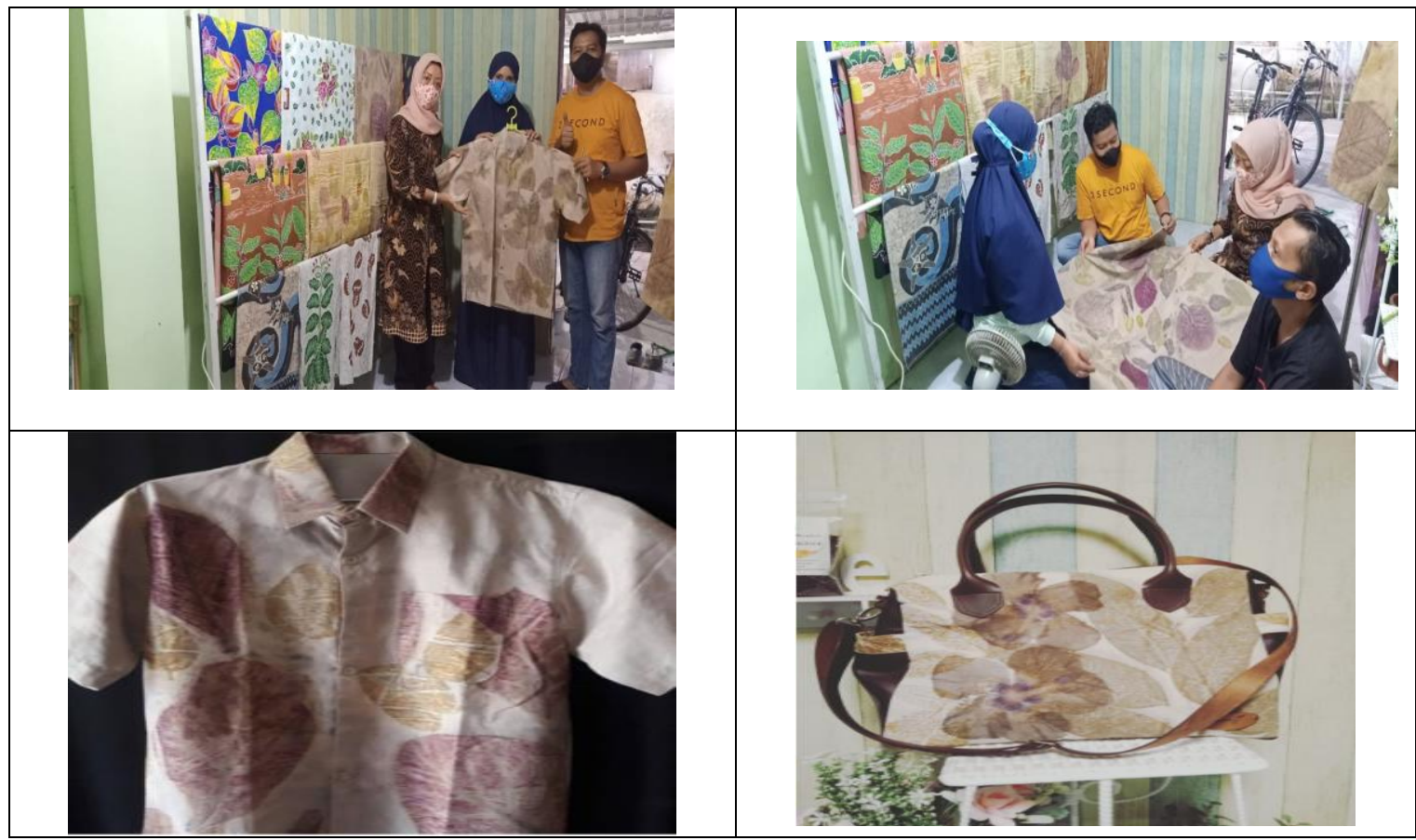

Gambar 4. Dokumentasi Kegiatan Pengabdian Masyarakat dan Hasil Kegiatan

\begin{tabular}{|c|c|c|}
\hline $\begin{array}{c}\text { Pembuatan konten di } \\
\text { Facebook }\end{array}$ & Pembuatan Intagram & $\begin{array}{c}\text { Youtube : Yuniat Batik } \\
\text { Jember }\end{array}$ \\
\hline 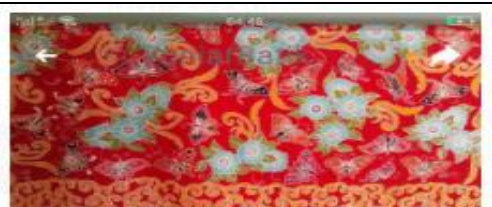 & $\begin{array}{ccc} & \\
\text { yuniarbtk } \quad 0 \quad & \vdots \\
12 & 29 & 9 \\
\text { Postin... Pengi... Mengi... }\end{array}$ & 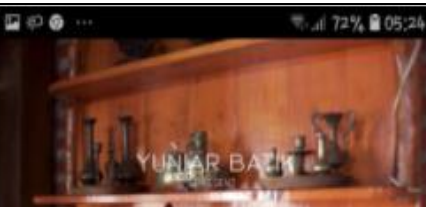 \\
\hline P. 19 YuniarBatik & $\begin{array}{l}\text { Batik Yuniar } \\
\text { Menyediakan Batik Tulis dan Batik } \\
\text { Cap }\end{array}$ & \\
\hline $\begin{array}{l}\text { C Telepon Sekarang } \bullet-- \\
\text { Fefi dan } 256 \text { lainnya } \\
\text { menyukai ini }\end{array}$ & $\begin{array}{l}\text { Menerima by request motif... lainnya } \\
\text { biolinky.co/yuniarbtk } \\
\text { Diikuti oleh fefidianal }\end{array}$ & $\begin{array}{l}\text { YUNIAR BATIK JEMBER } \\
19 \times \text { ditonton } 2 \text { bulan yang lalu }\end{array}$ \\
\hline Beranda Postingan Video Fotc & Kirim Pesan & 田 \\
\hline $\begin{array}{l}\text { Tulis sesuatu di } \\
\text { Halaman }\end{array}$ & 囲 & S Skykey Indo... SUBSCRIBE \\
\hline $\begin{array}{l}\begin{array}{l}\text { Bagikan } \\
\text { Foto }\end{array} \\
\end{array}$ & 1 & $\begin{array}{l}8 \text { subscriber } \\
\text { Komentar }\end{array}$ \\
\hline an YuniarRatik & Q & - Tulis komentar publik... \\
\hline
\end{tabular}

Gambar 5. Hasil Kegiatan berupa konten di link Facebook, Instagram dan youtube

Berdasarkan kegiatan pembinaan dan pendampingan kepada mitra yaitu ibu Yuniar pemilik usaha Eco Print Batik maka hasil evaluasi dan capaian kinerja program pengabdian meliputi:

a) Bertambahnya pengetahuan tentang strategi pemasaran produk, pemasaran berbasis teknologi informasi, dan strategi peningkatan kapasitas produksi

b) Kemampuan untuk mempraktekkan pembuatan Instagram

c) Kemampuan membuat 

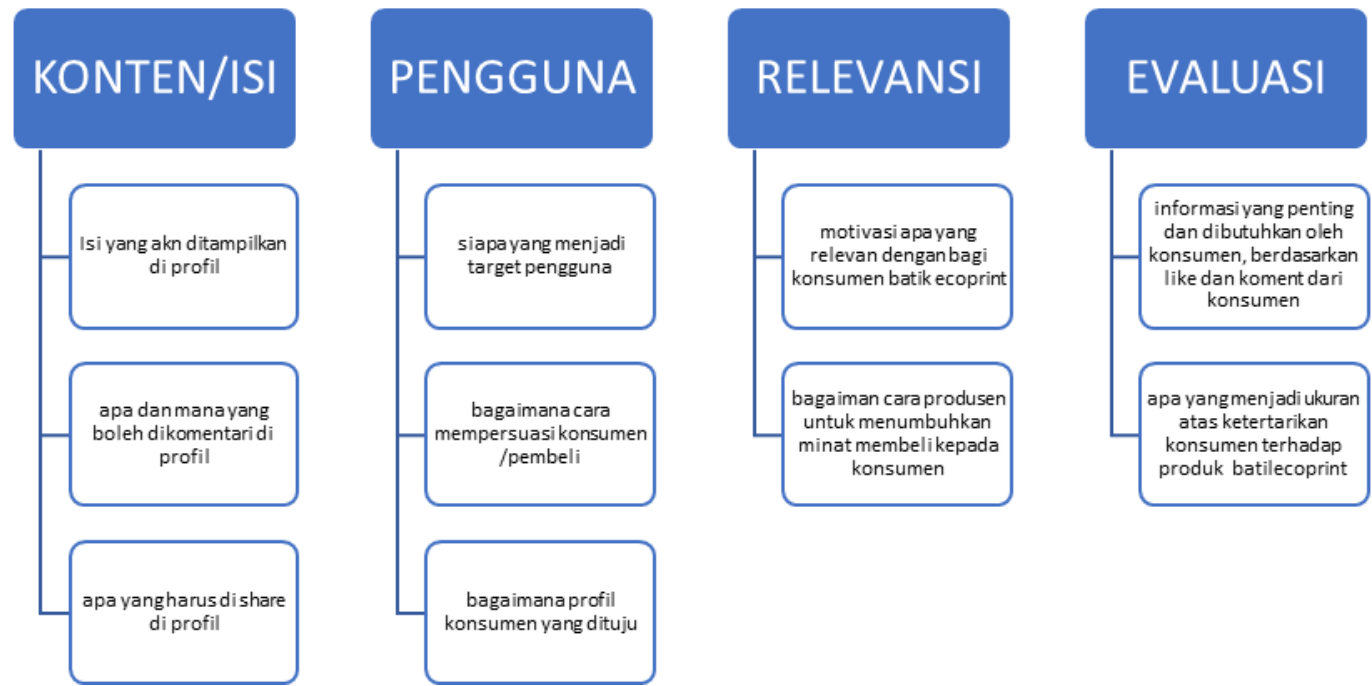

Gambar 5. Strategi Update Profil Pemasaran berbasis Sosial Media

\section{KESIMPULAN DAN SARAN}

\section{Kesimpulan}

Kesimpulan yang dapat diambil dari kegiatan ini adalah : dari kegiatan pengabdian berupa pelatihan dan pendampingan yang sudah dilakukan kepada mitra adalah adanya motivasi dari mitra Yuniar Batik terus mengembangkan usaha Eco Print ini untuk memanfaatkan sistem inforamasi e-commerce yang telah dibangun dalam rangka meningkatkan mutu penjualan batik dari mitra pengabdian ini, dimana sebelumnya penjualan batik dilakukan secara manual saat ini sudah dapat dilakukan dengan menggunakan atau memanfaatkan tehnologi online melalui promosi dengan memanfaatkan media sosial Facebook dan instagram.

\section{Saran Pengembangan Kegiatan}

Berdasarkan hasil kegiatan peengabdian yang sudah dilakukan oleh Tim maka rekomendasi yang dapat diberikan untuk pengembangan usaha mitra Batik Yuniar di masa mendatang meliputi :

a. Diterapkannya strategi pemasaran berbasis media sosial (penggunaan instagram) sebagai strategi perluasan pangsa pasar.

b. Meningkatkan kapasitas produksi, perbaikan mutu produk dan melalui penambahan jenis produk akhir yang dihasilkan yang lebih menarik dan marketable yang lebih berdaya saing di pasar global.

c. Perlu adanya bantuan dan pendampingan dari stakeholder seperti pemerintahan daerah khususnya dinas koperasi dan UMKM Kabupaten Jember, yang terkait dengan pengembangan usaha berupa akses permodalan dan perbaikan sistem pemasaran dengan memanfaatkan media e-commerce, sehingga produk UMKM yang dihasilkan kedepannya akan jauh lebih berkembang dan akan berdampak terhadap peningkatan pendapatan dan kesejahteraan para pengrajin batik khusunya Eco Print. proses pembuatan dan pengembangan aplikasi tersebut dapat berjalan sesuai dengan apa yang dinginkan oleh pihak mitra dan masyarakat.

\section{UCAPAN TERIMAKASIH}

Tim pelaksana pengabdian masyarakat mengucapkan terimakasih kepada Lembaga Penelitian dan Pengabdian Kepada Masyarakat Universitas Muhammadiyah Jember atas segala bantuan pendanaan dalam pengabdian ini, selain itu Tim juga mengucapkan terima kasih 
atas dukungan civitas akademika Universitas Muhammadiyah Jember sehingga Pengabdian berjalan sesuai dengan tujuan dan harapan.

\section{DAFTAR PUSTAKA}

Ahda, M., Perwitasari, D. A., Faridah, I. N., Yuni, E., \& Jannah, N. (2019). Pemahaman pembatik terhadap bahaya bahan kimia dan pewarna di area pembatik Gunungkidul. Seminar Nasional Hasil Pengabdian Kepada Masyarakat Universitas Ahmad Dahlan, September, 437-442.

Alamsyah, A. (2018). Kerajinan Batik dan Pewarnaan Alami. Endogami: Jurnal Ilmiah Kajian Antropologi, 1(2), 136. https://doi.org/10.14710/endogami.1.2.136-148

Kumalasari, Y. (2014). Pembinaan Dan Pemberdayaan Pengrajin Batik (Studi Di Dinas Koperasi, UKM, Perindustrian, Perdagangan Dan ESDM Kabupaten Sidoarjo Dan Industri Kecil Kampoeng Batik Jetis Kabupaten Sidoarjo). Jurnal Administrasi Publik Mahasiswa Universitas Brawijaya, 2(1), 66-70.

Noviyanti, R. (2017). Peran Ekonomi Kreatif Terhadap Pengembangan Jiwa Entrepreneurship di Lingkungan Pesantren: Studi Kasus di Pondok Modern Darussalam Gontor Putri 1. Jurnal Penelitian Ilmiah Intaj, 1(1), 77-99.

Prabawa, E. S., Supandi, \& Sulistiyanto. (2020). Pemberdayaan Kerajianan Batik dalam Mewujudkan Kemakmuran Ekonomi Masyarakat Mendukung Pertahanan Negara di Provinsi Jambi. Jurnal Ekonomi Pertahanan, 6(1), 19-32.

Sukarta, I. N., \& Sastrawidana, I. D. K. (2014). The Use of Agricultural Waste to Increase the Production Ligninolytic Enzyme by Fungus Polyporus sp. OALib, 01(03), 1-7. https://doi.org/10.4236/oalib.1100642

https://mediacenter.slemankab.go.id/batik-ecoprint-kontemporer-unik-dan-ramah- lingkungan/ Media Center 2019. Ba

Ecoprint: Kontemporer, Unik dan Ramah Lingkungan

https://www.bahankain.com/2021/02/23/cara-membuat-batik-eco-print, Bahankain, 2021, Cara Membuat Batik Eco Print

https://www.jawapos.com/features/04/09/2020/didik-edy-susilo-kembangkan-ecoprint-jadiproduk-unggulan, Jawa Pos.com, 2020, Didik Edy Susilo Kembangkan Ecoprint Jadi Produk Unggulan / 